\title{
Senior Citizens and E-commerce Websites: The Role of Perceived Usefulness, Perceived Ease of Use, and Web Site Usability
}

\author{
Terry J. Smith \\ Macon State College, Macon, GA, USA
}

\author{
terry.smith1@maconstate.edu
}

\begin{abstract}
Many companies now actively use the Web as a key marketing and sales vehicle for their goods or services. To be successful, e-commerce Web sites must be useful, easy to use, easy to navigate, and easy to understand - measures of the Technology Acceptance Model's (TAM) variables Perceived Usefulness and Perceived Ease of Use. Although many studies have used the model to better understand e-commerce, the problem is that they have ignored one very important external variable - the effects that an aging population may have on the usability the Internet and of ecommerce Web sites. As people age, they begin to experience problems with their vision, their hearing, cognitive functions, and their mobility. It was posited that the TAM and its variables of perceived ease of use and perceived usefulness, influenced by the product and services offered by the Web site, the usability of the Web site, and the senior's ability to use the Internet, determine a senior's attitude toward and behavioral intention to use e-commerce Web sites. It was found that the research model accurately reflects the effects of the aging process and that the perceived usefulness of e-commerce Web sites positively and significantly influenced a senior's attitude toward using and intention to use the Web sites. It was also found that a Web site's usability positively and significantly influenced the perceived ease of use of e-commerce Web sites.
\end{abstract}

Keywords: Technology Acceptance Model; Web site usability; E-commerce

\section{Introduction}

Conducting business over the Web has become a key component of business strategies. According to the U. S. Department of Commerce $(2004,2006 a, 2006 b, 2007)$ total retail e-commerce sales in 2007 were $\$ 136$ billion, an increase of $25.6 \%$ from the previous year and an amazing $207 \%$ increase compared to 2002 . E-commerce sales as a percentage of total retail sales also continued to increase and, for 2007, were at $3.3 \%$ of total retail sales. Despite the continued growth

Material published as part of this publication, either on-line or in print, is copyrighted by the Informing Science Institute. Permission to make digital or paper copy of part or all of these works for personal or classroom use is granted without fee provided that the copies are not made or distributed for profit or commercial advantage AND that copies 1) bear this notice in full and 2) give the full citation on the first page. It is permissible to abstract these works so long as credit is given. To copy in all other cases or to republish or to post on a server or to redistribute to lists requires specific permission and payment of a fee. Contact Publisher@InformingScience.org to request redistribution permission. in e-commerce and the potential for future growth in e-commerce, companies have reported problems in attracting new customers and retaining existing ones (Devaraj, Fan, \& Kohli, 2002) and face challenges in converting online visitors to real purchasers (C. Chen, 2003).

One of the ways to explain this is to apply the Technology Acceptance Model (TAM) (see Figure 1) which states that the success of a system can be deter- 
mined by user acceptance of the system, measured by two variables: the Perceived Usefulness of the system and the Perceived Ease of Use of the system (Davis, 1989). According to the model, a user's perceptions about a system's usefulness and ease of use result in an intention to use (or not use) the system (Davis, 1989; Venkatesh, 2000).

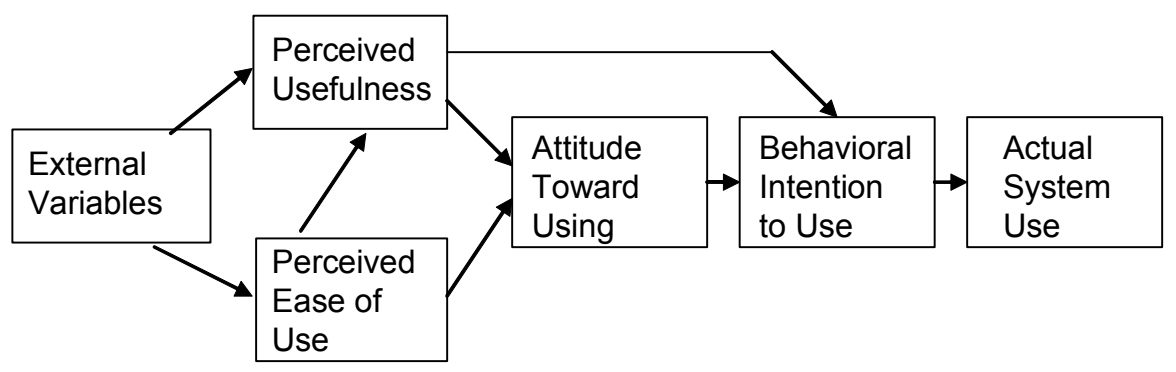

Figure 1. Technology Acceptance Model (TAM)

The TAM has been tested in many empirical studies (Burton-Jones \& Hubona, 2005), found to be highly valid and reliable (Koufaris, 2000), and is widely referenced (Devaraj et al., 2002). The external variables represent attributes or characteristics of the system, such as the overall design and features of the system, the user's computer skills, capabilities and abilities, and the user's knowledge, beliefs, and attitude toward computers. Perceived usefulness is defined as "the degree to which a person believes that using a particular system would enhance his or her job performance." Perceived ease of use refers to "the degree to which a person believes that using a particular system would be free of effort" (Davis, 1989, p. 320).

Data from the U. S. Census Bureau (2004) indicate that the U.S. population, when compared to the 2000 census and then adjusted for fertility, mortality, and international migration rate estimates, will increase $9.8 \%$ by 2010 , another $8.7 \%$ by 2020 , and another $8.3 \%$ by 2030 . Seniors, people 65 years of age and older (Fox, 2004), are estimated, based on this same data, to increase at a faster rate, a $15 \%$ increase by 2010 and a staggering $35.8 \%$ by 2020 . What is even more significant is that by 2030 the senior population will double and become almost $20 \%$ of the U.S. population. This is important because the senior population is increasingly using the Internet to communicate via e-mail with family and friends and to get information and evaluate services (Hanson, 2001). Seniors also conduct e-commerce transactions, utilize online access to financial services such as banks and brokerage firms, obtain travel information, and research health-related services.

A problem facing the designers of e-commerce Web sites is that seniors face challenges to using computers and navigating Web sites (Gregor \& Newell, 2001; Hanson, 2001) since, as people age, their sight, their cognitive functions, and their motor-skills may change (Becker, 2004; Gregor \& Newell, 2001; Hawthorn, 2000). Since the usability of an e-commerce Web site can be a predictor of success (Agarwal \& Venkatesh, 2002; L. Chen, Gillenson, \& Sherrell, 2004; Gefen, Karahanna, \& Straub, 2003), these aging problems have an impact on the ability for seniors to effectively use the Web (Becker, 2004) and to conduct e-commerce transactions.

It is the seniors' desire to use e-commerce Web sites and the design of e-commerce Web sites that were the focus of this research. Prior studies of the TAM and e-commerce Web sites have not been conducted with sole participation from the senior population. It was important to address this problem by conducting research on the use of e-commerce Web sites with representation from this target group because the effects of aging can impede a senior's ability to effectively use the Internet for information retrieval and the purchasing of products and services. 
The rest of the paper is organized as follows. The next two sections discuss related studies and include statistical data that is used to support the research goal and objectives. The fourth section presents the plan for conducting the research study, the questionnaires that were used to obtain data for analysis, and the processes by which the data were analyzed. The fifth section presents a detailed explanation of the data collected, the analysis of the data, and the findings from the PLSGraph analysis. The last includes a discussion concerning the conclusions of the researcher and recommendations for future work.

\section{Literature Review}

According to the National Eye Institute (2002), age-related eye diseases can result in vision impairment up to and including complete blindness. As the population ages, three very common types of vision problems will continue to increase: age-related macular degeneration, cataracts, and glaucoma. Age-related macular degeneration is one of the most common and most severe causes of vision impairment in seniors, a retina degeneration that results in a loss of sharp central vision. Cataracts, or a clouding of the eye's lens, can result in a person's vision becoming blurred. Glaucoma is a disease that affects the eye's optical nerve and, if detected early, can be controlled. But, any loss of vision is, unfortunately, irreversible. The potential loss of vision by any of these diseases could impact an individual's ability to use computer interfaces (Jacko et al., 2003), a critical requirement for the successful use of B2C e-commerce Web sites.

Seniors can also experience problems "...with fine motor coordination such as using a computer mouse to navigate through a site or positioning the cursor on a desired target" (Rogers \& Fisk, 2002, p. 261) and "factors such as arthritis and loss of general hand and finger dexterity can play a role in impaired control of the usual input devices for computers (e.g., keyboard and mouse)" (p. 248). The hands and fingers are one of the areas of the body that experience a loss of motor functions and this can affect an individual's use of a computer keyboard, a computer mouse, and/or a trackball.

Cognitive load theory is based on the amount of working memory capacity, or the amount of information that a human can hold and analyze (Becker, 2004; Van Gerven, Paas, Van Merrienboer, Hendriks, \& Schmidt, 2003). According to Van Gervan et al. there are three cognitive declines that seniors may experience: 1) a decrease in working-memory capacity, often seen as short-term memory loss; 2) a decline in the rate at which information can be processed and understood; and 3) a decline in the ability to ignore irrelevant information. As a result, seniors tend to perform less well on tasks that involve the use of short-term and working memory (Burton-Jones \& Hubona, 2005; Cutler, 2005).

It is a combination of the growth in the senior population, the increased usage of computers by seniors, the limitations and disabilities that result from the aging process, and a desire to utilize new technologies that presents both opportunities and challenges to $\mathrm{B} 2 \mathrm{C}$ e-commerce companies. As Rettie (2002) noted, marketers need to recognize this opportunity and respond accordingly.

In reviewing the demographic data from a sample of the studies that have been conducted against the TAM and e-commerce (see Table 1) neither the age of the participants nor the limitations that occur as a result of the aging process were considered as variables that could affect the perceived usefulness or perceived ease of use of the Web site. Only the study by Park (2003) reported that 44 of the 733 consumers in the research were 65 years of age or older, but the data from those participants was not isolated for analysis. 
Table 1. Research on TAM and Participant Age Distribution

\begin{tabular}{|c|c|c|c|}
\hline Author & Purpose of the Research & Participants & $\begin{array}{l}\text { Senior } \\
\text { Participants }\end{array}$ \\
\hline $\begin{array}{l}\text { L. Chen, } \\
\text { Gillenson, \& } \\
\text { Sherrell } \\
(2004)\end{array}$ & $\begin{array}{l}\text { Proposed that five additional variables } \\
\text { influence the perceived usefulness and } \\
\text { perceived ease of use of a Web site: } \\
\text { Product Offering, Information Richness, } \\
\text { Storefront Usability, Perceived Service } \\
\text { Quality, and Perceived Trust. }\end{array}$ & $\begin{array}{l}253 \text { responses to an } \\
\text { online survey. Seven of } \\
\text { the } 253 \text { responses were } \\
\text { over the age of } 50 .\end{array}$ & $\begin{array}{l}\text { None } \\
\text { identified. }\end{array}$ \\
\hline $\begin{array}{l}\text { Gefen, } \\
\text { Karahanna, \& } \\
\text { Straub (2003) }\end{array}$ & $\begin{array}{l}\text { Trust is then added to the TAM as a } \\
\text { construct that influences the consumer's } \\
\text { intention to use the Web site. }\end{array}$ & $\begin{array}{l}196 \text { undergraduate and } \\
\text { graduate students from } \\
\text { a business school in the } \\
\text { mid-Atlantic region; } \\
188 \text { in their twenties. }\end{array}$ & $\begin{array}{l}\text { None } \\
\text { identified. }\end{array}$ \\
\hline $\begin{array}{l}\text { Klopping \& } \\
\text { McKinney } \\
(2004)\end{array}$ & $\begin{array}{l}\text { Study to establish that e-commerce is an } \\
\text { information system technology that can be } \\
\text { tested using the TAM. }\end{array}$ & $\begin{array}{l}\text { A Web-based survey } \\
\text { responded to by } 253 \\
\text { undergraduates; } 96 \% \\
\text { were between the ages } \\
\text { of } 20 \text { to } 25 \text {. }\end{array}$ & $\begin{array}{l}\text { None } \\
\text { identified. }\end{array}$ \\
\hline $\begin{array}{l}\text { Koufaris } \\
(2000)\end{array}$ & $\begin{array}{l}\text { Conducted three field studies to better } \\
\text { understand the impact of the design of the } \\
\text { Web site on the consumer buying process. }\end{array}$ & $\begin{array}{l}\text { Study 1: } 332 \\
\text { participants; } 79.5 \% \\
\text { under } 35 \text { years of age. } \\
\text { Study 2: } 280 \\
\text { participants; normal age } \\
\text { distribution. } \\
\\
\text { Study 3: } 61 \text { MBA } \\
\text { students; } 85 \% \text { were } \\
\text { between the ages of } 26 \\
\text { to } 45 \text {. }\end{array}$ & $\begin{array}{l}\text { None } \\
\text { identified. } \\
\text { None } \\
\text { identified } \\
\text { although the } \\
\text { "normal" } \\
\text { distribution } \\
\text { indicates that } \\
\text { some seniors } \\
\text { participated. } \\
\text { None } \\
\text { identified. }\end{array}$ \\
\hline $\begin{array}{l}\text { Lederer, } \\
\text { Maupin, } \\
\text { Sena, \& } \\
\text { Zhuang } \\
(2000)\end{array}$ & $\begin{array}{l}\text { To validate the application of the TAM to } \\
\text { Internet Web sites and to identify the } \\
\text { features these Web sites must exhibit to be } \\
\text { considered useful and easy to use. }\end{array}$ & $\begin{array}{l}\text { An e-mail survey to } \\
\text { members of work- } \\
\text { related Internet } \\
\text { newsgroups; responded } \\
\text { to by } 163 \text { individuals } \\
\text { who use the Internet for } \\
\text { their jobs. }\end{array}$ & $\begin{array}{l}\text { None } \\
\text { identified; the } \\
\text { average age } \\
\text { of the } \\
\text { respondents } \\
\text { was } 37.4 \\
\text { years. }\end{array}$ \\
\hline $\begin{array}{l}\text { O'Donnell } \\
(2002)\end{array}$ & $\begin{array}{l}\text { Proposed and tested a theoretical model of } \\
\text { the impact of Web site design features on } \\
\text { trust generation and the final purchase } \\
\text { decision. }\end{array}$ & $\begin{array}{l}297 \text { participants } \\
\text { returned usable } \\
\text { questionnaires; age } \\
\text { range }=22 \text { to } 44 \text { years } \\
\text { of age. } \\
\end{array}$ & $\begin{array}{l}\text { No seniors } \\
\text { participated. }\end{array}$ \\
\hline Park (2003) & $\begin{array}{l}\text { Compared four models (i.e., the Theory of } \\
\text { Reasoned Action (TRA), the Theory of } \\
\text { Planned Behavior (TPB), the TAM, and a } \\
\text { decomposed TPB model) to predict and } \\
\text { understand the consumer's online shopping } \\
\text { experience. }\end{array}$ & $\begin{array}{l}733 \text { consumers } \\
\text { participated in an online } \\
\text { survey. }\end{array}$ & $\begin{array}{l}6 \% \text { or } 44 \text { of } \\
\text { the } \\
\text { consumers } \\
\text { were over the } \\
\text { age of } 65 .\end{array}$ \\
\hline
\end{tabular}




\begin{tabular}{|l|l|l|l|}
\hline Author & Purpose of the Research & Participants & $\begin{array}{l}\text { Senior } \\
\text { Participants }\end{array}$ \\
\hline $\begin{array}{l}\text { Suh \& Han } \\
(2003)\end{array}$ & $\begin{array}{l}\text { Introduced the issues of security and } \\
\text { ultimately trust in an e-commerce Web site. }\end{array}$ & $\begin{array}{l}\text { 502 responses to a } \\
\text { Web-based survey of } \\
\text { Internet banking users. } \\
\text { Only four of the } \\
\text { respondents were over } \\
\text { the age of 50. }\end{array}$ & $\begin{array}{l}\text { No seniors } \\
\text { identified as } \\
\text { participants }\end{array}$ \\
\hline
\end{tabular}

\section{Related Work}

E-commerce Web sites are, according to Gefen et al. (2003), information technologies against which user acceptance behavior can be explained using the TAM. Online users, after all, are information technology users and the more useful and easy to use the site, the more the Web site will be used. Within the body of research on the TAM, there are several studies that modified the TAM and focused on its use in predicting acceptance of the Internet and e-commerce systems.

Koufaris (2000) focused on understanding what motivates consumers to initially buy from an ecommerce Web site and then later return as a repeat customer. The research included two ecommerce Web sites - Kozmo.com and Booksamillion.com - and three studies conducted against the constructs of the TAM. Koufaris found that: 1) perceived usefulness had much more of an effect on the decision to shop than did ease of use since the Web site must fulfill a consumer's shopping needs; and 2) the overall experience of using the Web site and finding the products the consumer desires can have a significant impact on both the initial shopping experience as well as the consumer's intention to return to that site.

Gefen, Straub, and Boudreau (2000) used a travel Web site, Travelocity.com, to test three constructs of the TAM: 1) perceived usefulness; 2) perceived ease of use; and 3) intention to use. The authors collected survey data from 160 students to compare and contrast three data analysis techniques: linear regression analysis, LISREL, and partial least squares. All three techniques produced the same result in that both perceived usefulness and perceived ease of use significantly influenced the intention to use the Web site.

Liang and Lai (2002) used three online bookstores in Taiwan: 1) Kingston.com.tw; 2) Books.com.tw; and 3) Sanmin.com.tw. The goal was to examine the effects of each store's design on the consumer's decision to purchase from the Web site. Thirty students visited all three sites, purchased two items from any of the stores, and then completed a questionnaire about the pre-purchase and shopping experience. The results showed that store design was as important as the product's price and that consumers are more likely to purchase from well-designed Web sites.

Gefen et al. (2003) analyzed survey data collected from 196 graduate and undergraduate students. The data were captured on a questionnaire and the responses were based on the participant's last experience purchasing a book or $\mathrm{CD}$ from an online vendor. The authors were testing a model based on the TAM that included the constructs perceived usefulness, perceived ease of use, intended use, and a new construct, trust. The findings showed that trusting the Web site and the vendor is important and that the technological aspects of the Web site, specifically the interface, influenced both the initial decision to buy and then to return to the Web site in the future.

Klopping and McKinney (2004) tested the TAM in an attempt to better understand how and why people adopt and use e-commerce, referred to as online shopping. The authors modified the TAM in two important ways: 1) they removed the relationship between perceived usefulness and perceived ease of use; and 2) they added a direct relationship between perceived usefulness and actual usage. Five hypotheses proposed that the TAM, the construct perceived usefulness, and the construct perceived ease of use were all positively related to both the intention to use online 
shopping and to actually shop online. The results of the study support the authors' modifications to the TAM and that perceived usefulness does influence the actual usage of the system. Perceived usefulness was also found to have a greater influence on the intention to use the Web site when compared to the perceived ease of use of the Web site.

L. Chen et al. (2004) modified the TAM and added six additional variables to the model. The six variables were: Product Offerings, Information Richness, Usability of the Storefront, Perceived Service Quality, Compatibility, and Perceived Trust. An analysis of 253 responses to an online survey indicated that the usability of the storefront was found to positively influence the perceived ease of use of the storefront. Another key finding was that the Web site's usability was more important than the product offerings of the vendor. Product offerings and the compatibility of the Web site to the user's needs were found to have a significant influence on perceived usefulness. Of particular importance to this researcher was that the usability of the storefront had a significant influence on the perceived ease of use of the Web site.

In an international setting, Singh, Fassott, Chao, and Hoffman (2006) tested a TAM that included a new construct, Cultural adaptation. The construct was posited to influence the TAM's Perceived ease of use of a Web site and the Attitude toward using a Web site. Cultural adaptation was defined as a Web site's ability s to present product content in formats applicable to different countries and cultures. The study showed that Cultural adaptation had a significant effect on the Perceived ease of use of the Web site, and that the remaining constructs in the TAM, Perceived usefulness and Perceived ease of use, were positively related to the Attitude toward using the Web site and ultimately the Behavioral intention to use the Web site.

Savitskie, Royne, Persinger, Grunhagen, and Witte (2007) modified the TAM and added two constructs that were posited to influence the perceived usefulness of an e-commerce Web site. The authors added a construct Computer affinity to represent a user's attitude toward using computers. Also added to the model was a second construct, Involvement, to represent the user's attachment to the products offered for sale on an e-commerce Web site. An analysis of 292 responses to a questionnaire indicated that: 1) the construct Involvement had a significant effect on Perceived usefulness; and 2) Computer affinity did not have a significant effect on Perceived usefulness. Consistent with previous studies, Perceived usefulness was found to have a greater influence on the intention to use the Web site when compared to the Perceived ease of use of the Web site.

In summary, the application of the TAM and its use when explaining the adoption of e-commerce Web systems has been established in prior studies. These studies have validated the TAM and its reliable constructs of perceived usefulness, perceived ease of use, the attitude toward using the Web system, and the behavioral intention to use the Web system and have augmented the TAM with other constructs to better explain the relationship and significance of the TAM constructs.

\section{Research Methodology}

\section{Model and Constructs}

The research model showing hypotheses is depicted in Figure 2. The null hypotheses were as follows:

- H1: The senior's perception of the products and services offered by an e-commerce Web site will not have a significant effect on the senior's perceived usefulness of an ecommerce Web site. 
- H2: The senior's perception of the perceived usefulness of an e-commerce Web site will not have a significant effect on the senior's attitude toward using an e-commerce Web site.

- H3: The senior's perception of the usability of an e-commerce Web site will not have a significant effect on the senior's perceived ease of use of an e-commerce Web site.

- H4: The senior's perception of the usability of the Internet will not have a significant effect on the senior's perceived ease of use of an e-commerce Web site.

- H5: The senior's perceived ease of use of an e-commerce Web site will not have a significant effect on the senior's attitude toward using an e-commerce Web site.

- H6: The senior's perceived usefulness an e-commerce Web site will not have a significant effect on the senior's behavioral intention to use an e-commerce Web site.

- H7: The senior's perceived ease of use of an e-commerce Web site will not have a significant effect on the senior's perceived usefulness of an e-commerce Web site.

- H8: The senior's attitude toward using an e-commerce Web site will not have a significant effect on the senior's behavioral intention to use an e-commerce Web site.

- H9: The senior's behavioral intention to use an e-commerce Web site will not have a significant effect on predicting the senior's actual use of an e-commerce Web site.

The research model also contains many dependent-independent construct relationships that were analyzed. The relationships are as follows:

- Perceived Usefulness of the Web Site is dependent on two independent constructs, Perceived Ease of Use of the Web Site and Products and Services.

- Perceived Ease of Use of the Web Site is dependent on two independent constructs, Web Site Usability and Internet Usability.

- Attitude toward Using the Web Site is dependent on two independent constructs, Perceived Ease of Use of the Web Site and Perceived Usefulness of the Web Site.

- Behavioral Intention to Use the Web Site is dependent on two independent constructs, Perceived Usefulness of the Web Site and Attitude toward Using the Web Site.

- The primary dependent construct in the study is Actual System Usage of the Web Site and is dependent on one independent construct, Behavioral Intention to Use the Web Site.

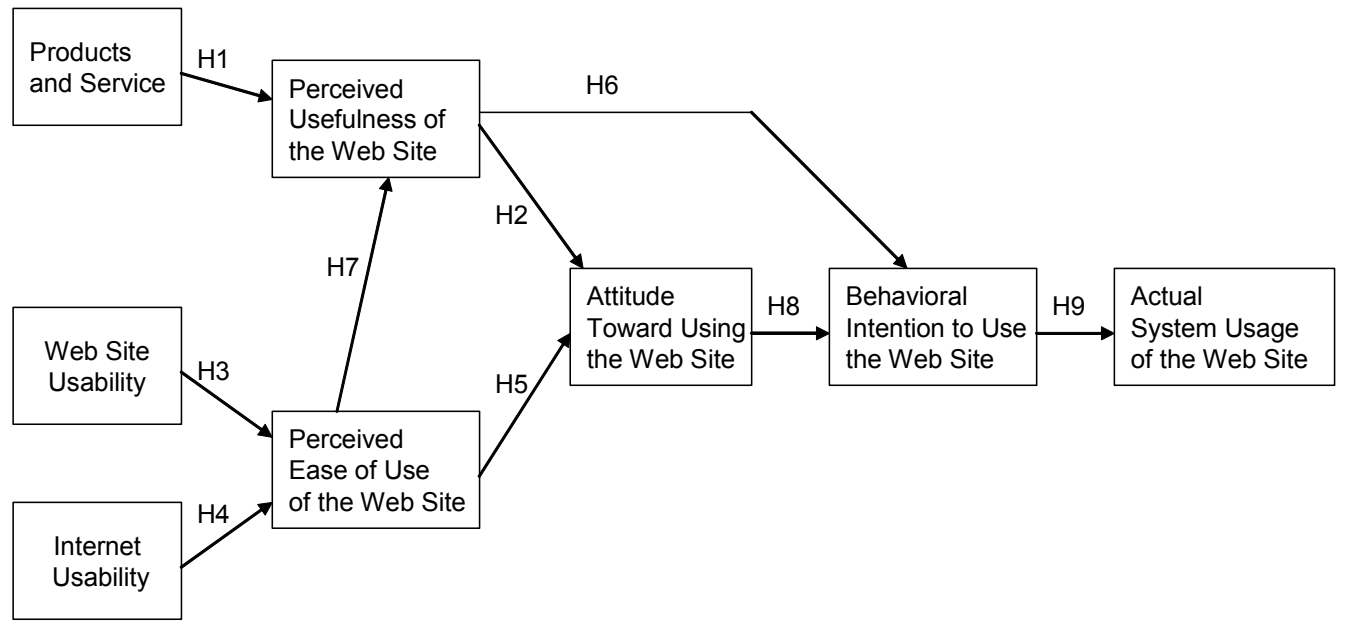

Figure 2. Research Model showing Hypotheses 


\section{Research Overview}

The researcher conducted a field experiment with a purposeful sample of seniors from two South Florida organizations - the Lifelong Learning Institute at Nova Southeastern University and the Daniel Cantor Senior Center in Broward County. Each participant searched for and selected products, either an airline trip or a book, from four retail Web sites in two industries - travel and online bookstores. The Web sites used were Orbitz.com, Travelocity.com, Booksamillion.com, and Barnesandnoble.com.

The researcher selected an empirical method of study by observing each participant during the product search on each of the four e-commerce Web sites, logging data and comments about the participant's task experience. After the search was completed, the researcher provided a post-task questionnaire to the participant to capture quantitative data about that shopping experience and that Web site. Since this research involved human subjects, Institutional Review Board approval was obtained before the pilot and the study were conducted.

To ensure the replicability and consistency of each test of each Web site by every participant, instructions detailing the tasks to be accomplished were developed for each of the four e-commerce Web sites and each participant followed the instructions and executed the steps necessary to identify and select a book or an airline trip. To improve the internal validity by acknowledging the influence of maturation effects (Sekaran, 2003), the four Web sites were tested by each participant in random order.

This study did not require the participant to complete the purchase of a book or an airline reservation by submission of credit card information. A review of a sample of prior research on ecommerce shows that the ease of use and the usefulness of a Web site can be determined without actually purchasing a product or a service (Agarwal \& Venkatesh, 2002; C. Chen, 2003; L. Chen et al.; Gefen et al., 2000; Gefen et al., 2003; Liang \& Lai, 2002; O’Donnell, 2002; Park, 2003).

\section{Questionnaires}

Two questionnaires were used in the study. The "Demographic and Computer Usage" questionnaire was used to capture demographic information about each participant and each participant's experience using computers and the Internet. It was also used to capture data about the number of times each participant shopped using an e-commerce Web site and provided the data that was used to measure the research model's construct, Actual System Usage of the Web Site. The second questionnaire, called the post-task questionnaire, was used to capture the participant's impression of the shopping experience on each of the four Web sites used in the study, providing the data used to measure the remaining constructs in the research model.

The questionnaires were created using an aggregate of questions from questionnaires that were used in prior studies. C. Chen (2003) was used as the source for the questions on Internet Usability. L. Chen et al. (2004) was used as the source for the questions on the remaining constructs in the proposed model. The questions were positively worded, with three exceptions. Three questions on Web Site Usability were borrowed from L. Chen et al. and negatively worded. According to Sekaran (2003), good questionnaires use positively and negatively worded questions because this reduces the tendency for participants to always respond toward the same end of the scale.

Consistent with prior studies of the TAM, the 7-point Likert scale was used to capture the responses to the construct questions. The range of the scale for the post-task questionnaire is from 1 to 7 , from "strongly disagree" to "strongly agree" respectively. The range of the scale on the "Demographic and Computer Usage" questionnaire, used to capture information about the num- 
ber of purchases made using e-commerce Web sites, is also from 1 to 7 , from having made " 0 " purchases to having made purchases "More than 10 times" respectively.

\section{Usability Test Log}

Since the usability of each e-commerce Web site was studied, a document, called the "Usability Test Log", was used to collect quantitative and qualitative data about the experience of the participant during the product search task on each of the four Web sites. The quantitative performance data that were collected, as suggested by Mayhew (1999) and Coyne and Nielsen (n.d.), included: 1) task completion times; 2) whether the product search was completed successfully; 3 ) the number of requests for help or assistance; and 4) the number of errors made during the product search. Qualitative data, in the form of the researcher's impression of the participant's experience and verbal comments made by the participant, were also captured during the product search task.

\section{Pilot}

Four people representative of the population under study were recruited to validate the task instructions and the questionnaires. As a result of this pilot, the questionnaires were validated to ensure that the questions were understandable and specific to evaluating the task of e-commerce shopping. Changes were made to the task instructions to reflect modifications that were made to Web pages on the four Web sites.

\section{Results Analysis}

The data collected on the post-task questionnaires were analyzed using PLS-Graph version 03.00 Build 1126, and XLSTAT, an Excel add-in that was purchased from Addinsoft Inc. XLSTAT was used to test reliability of the measurement scales and to format the input files used by PLSGraph.

PLS-Graph takes a conservative modeling approach that uses ordinary least squares regressions to estimate the loadings between items and constructs, the path coefficients, and the correlations between the constructs in the proposed research model (Chin, 1998). Although these results are provided at the same time, the measurement model was first assessed for reliable and valid measures of the constructs, followed by an assessment of the structural model, and then the hypothesis testing. The output from PLS-Graph was used for convergent and discriminant validity testing as well as for testing the significance of the causal paths and construct relationships.

\section{Hypothesis Testing}

The statistical significance of the path coefficients between the constructs was used to either "reject" or "fail to reject" the null hypotheses. Path coefficients, produced as output from PLS-Graph, were interpreted as regression coefficients in multiple regression analysis (Kline, 2005). PLS-Graph also calculated $t$-values that were used in testing the significance of the hypothesized relationships (Gefen et al., 2000).

The statistical significance is based on the selection of the significance level of the test. The significance level or alpha ( $\alpha$ was set at .05, a conventional level (Cohen, 1988; Kline, 2004), which establishes the probability of making a Type I error. A Type I error is the probability of incorrectly rejecting a true null hypothesis (Cohen, 1988; Kline, 2004). For this study, there is only a small probability $(<5 \%)$ that a true hypothesis will be falsely rejected. The probability of mak- 
ing a Type II error or failing to reject a false null hypothesis (Cohen, 1988; Kline, 2004) was not determined prior to conducting this study.

\section{Sample Size}

PLS-Graph requires the minimum number of data cases to be at least 10 times the highest number of items used to measure a research model's construct (L. Chin, 1998; Gefen et. al., 2000), or for this study a minimum of 60 data cases. Since the study involves the use of four Web sites and a product search on each Web site generated one data case, a minimum of 15 participants and tests on all four of the test Web sites were required to obtain the minimum number of 60 data cases.

\section{Results}

From August 10, 2006 to October 17, 2006, the researcher made presentations and met with the members of the Lifelong Learning Institute and the students and staff from the SeniorNet training program at the David Cantor Senior Center. As a result of these visits, a total of 25 people volunteered and 21 of them participated in the study.

The participants averaged 76 years of age and ranged in age from 66 to 86 years. Gender was unevenly distributed whereby $81 \%$ of the participants were female and $19 \%$ of them were male. Twenty of the participants have Internet access in their home, with $43 \%$ of them using a highspeed data line and the remainder using a dial-up connection. All of the participants own a computer, have access to the Internet, and have used the Internet in the past 6 months, thus meeting the requirements for participation in this study of e-commerce Web site usability.

Guided by the steps in the test script, each participant conducted the product searches by performing the same tasks. The participant followed the task instructions to select a book on the bookstore Web sites and to select an airline trip on the travel Web sites and then completed a questionnaire to capture information about the search and selection experience on the Web site. The researcher made every effort to see to it that every participant felt comfortable with the test environment and the test process. The goal was to minimize or eliminate any obstacles that could prevent the participant from successfully completing the task scenarios. To accommodate the busy schedules of many of the participants, testing was conducted concurrently with 2 to 3 participants in 5 of 12 test sessions.

The researcher did not answer any questions on how to navigate or use the Web site nor did the researcher in any way bias or influence any participant's answers to the questionnaires. Participants could decide at any time to stop or abandon a product search on any of the four test Web sites. If that happened, the participant could choose to complete the post-task questionnaire on that experience.

The researcher observed each participant, with a good view of the computer monitor, and maintained a $\log$ of each product search experience by writing down the start and stop times of the test, whether or not the product search was successful, any requests for assistance or help, and any errors made during the test. The researcher also wrote down comments about each task, especially noting the step in the task instruction if a participant exhibited signs of frustration, annoyance, or misunderstood something. The goal was to capture an impression of either the difficulties each participant faced or the ease with which each participant navigated the Web site.

After completing any product search and post-task questionnaire, the participant was allowed to stop, rest, and even arrange to resume at a later time or date. The quantitative data collected on any Web site test were used, although clearly data from all four Web sites were desired. Therefore, because the researcher had concerns that some participants may get tired or even frustrated 
and withdraw from the research, not all product searches on all four of the Web sites by a participant were mandatory. Because this was a test about e-commerce Web site usability, the quantitative and qualitative data collected from any product search on any of the Web sites were used in the data analysis and final report. The 21 participants completed a total of 72 post-task questionnaire responses and the responses were spread fairly evenly across the four Web sites, but slightly favoring the online bookstores.

\section{Reliability and Validity of the Measures}

The responses to the questionnaires were keyed into an Excel spreadsheet. The responses to the negatively worded items, numbers 23, 24, and 25 on the construct Web Site Usability, were reversed during data entry. The spreadsheet was then used as data input to the PLS-Graph program and the program generated the Average Variance Extracted (AVE), path coefficients, $t$ statistics, and variances using a bootstrapping resampling technique. Bootstrapping is a standard approach used by PLS-Graph that resamples with replacement from the original sample and for this study 500 resamples were used for significance testing of the path estimates (Chin, 1998).

The means, standard deviations, factor loadings, Cronbach's alpha (produced by the XLSTAT add-in), and the AVE for the post-task questionnaire items and the constructs are shown in Table 2. On a scale from 1 to 7, from "strongly disagree" to "strongly agree" respectively, the range of the means of the constructs ranged from a low of 4.76 to a high of 5.15, all above the "neutral" or middle of the Likert scale. The highest construct was Attitude toward Using with a mean of 5.15 followed closely by the constructs Web Site Usability at 5.08 and Internet Usability at 5.04. The lowest construct, with a mean of 4.76, was Behavioral Intention to Use.

Table 2. Summary of Measurement Scales

\begin{tabular}{|c|c|c|c|c|c|c|}
\hline Construct & $\begin{array}{l}\text { Item } \\
\text { Code }\end{array}$ & Items & Mean & $\begin{array}{l}\text { Standard } \\
\text { Deviation }\end{array}$ & $\begin{array}{l}\text { Cronbach's } \\
\text { Alpha }\end{array}$ & $\begin{array}{l}\text { Average } \\
\text { Variance } \\
\text { Extracted }\end{array}$ \\
\hline \multicolumn{3}{|c|}{ Internet Usability } & 5.04 & & 0.828 & 0.564 \\
\hline & IU1 & $\begin{array}{l}\text { The Internet makes my life more } \\
\text { interesting. }\end{array}$ & 5.92 & 1.31 & & \\
\hline & IU2 & I enjoy shopping online. & 4.24 & 1.80 & & \\
\hline & IU3 & $\begin{array}{l}\text { The Internet has brought great } \\
\text { convenience to my life. }\end{array}$ & 5.38 & 1.51 & & \\
\hline & IU4 & $\begin{array}{l}\text { The Internet makes my life eas- } \\
\text { ier. }\end{array}$ & 5.26 & 1.52 & & \\
\hline & IU5 & Shopping online is very easy. & 4.40 & 1.84 & & \\
\hline \multicolumn{3}{|c|}{ Behavioral Intention to Use the Web Site } & 4.76 & & 1.000 & 1.000 \\
\hline & BI1 & $\begin{array}{l}\text { I intend to use "the virtual store" } \\
\text { (e.g. purchase a product or seek } \\
\text { product information). }\end{array}$ & 4.76 & 1.94 & & \\
\hline \multicolumn{3}{|c|}{ Perceived Ease of Use of the Web Site } & 4.90 & & 0.986 & 0.948 \\
\hline & PEOU1 & $\begin{array}{l}\text { Learning to use "the virtual } \\
\text { store" was easy for me. }\end{array}$ & 4.97 & 1.88 & & \\
\hline
\end{tabular}




\begin{tabular}{|c|c|c|c|c|c|c|}
\hline \multirow[t]{5}{*}{ Construct } & $\begin{array}{l}\text { Item } \\
\text { Code }\end{array}$ & Items & Mean & $\begin{array}{c}\text { Standard } \\
\text { Deviation }\end{array}$ & $\begin{array}{l}\text { Cronbach's } \\
\text { Alpha }\end{array}$ & $\begin{array}{l}\text { Average } \\
\text { Variance } \\
\text { Extracted }\end{array}$ \\
\hline & PEOU2 & $\begin{array}{l}\text { I found it easy to use "the virtual } \\
\text { store" to find what I want. }\end{array}$ & 4.99 & 1.83 & & \\
\hline & PEOU3 & $\begin{array}{l}\text { My interaction with the "virtual } \\
\text { store" was clear and understand- } \\
\text { able. }\end{array}$ & 4.85 & 1.87 & & \\
\hline & PEOU4 & $\begin{array}{l}\text { It was easy for me to become } \\
\text { skillful at using "the virtual } \\
\text { store". }\end{array}$ & 4.81 & 1.90 & & \\
\hline & PEOU5 & $\begin{array}{l}\text { I found "the virtual store" easy } \\
\text { to use. }\end{array}$ & 4.88 & 1.90 & & \\
\hline \multicolumn{3}{|c|}{ Perceived Usefulness of the Web Site } & 4.86 & & 0.929 & 0.824 \\
\hline & PU1 & $\begin{array}{l}\text { Using "the virtual store" would } \\
\text { improve my performance in } \\
\text { shopping or information seeking } \\
\text { (e.g. save time or money). }\end{array}$ & 5.07 & 1.80 & & \\
\hline & PU2 & $\begin{array}{l}\text { Using "the virtual store" would } \\
\text { increase my productivity in } \\
\text { shopping or information seeking } \\
\text { (e.g. make purchase decisions or } \\
\text { find product information within } \\
\text { the shortest time frame). }\end{array}$ & 4.86 & 1.83 & & \\
\hline & PU3 & $\begin{array}{l}\text { Using "the virtual store" would } \\
\text { enhance my effectiveness in } \\
\text { shopping or information seeking } \\
\text { (e.g. get the best deal or find the } \\
\text { most information about a prod- } \\
\text { uct). }\end{array}$ & 4.78 & 1.81 & & \\
\hline & PU4 & $\begin{array}{l}\text { I found "the virtual store" very } \\
\text { useful in my shopping or infor- } \\
\text { mation seeking. }\end{array}$ & 4.72 & 1.88 & & \\
\hline \multicolumn{3}{|c|}{ Products and Services } & 4.97 & & 0.865 & 0.785 \\
\hline & PO1 & $\begin{array}{l}\text { "The virtual store" has a vast } \\
\text { selection of products. }\end{array}$ & 5.19 & 1.62 & & \\
\hline & PO2 & $\begin{array}{l}\text { "The virtual store" offers lower } \\
\text { prices than traditional stores for } \\
\text { the same products. }\end{array}$ & 4.67 & 1.72 & & \\
\hline & PO3 & $\begin{array}{l}\text { Overall, I like the product offer- } \\
\text { ings of "the virtual store". }\end{array}$ & 5.04 & 1.73 & & \\
\hline \multicolumn{3}{|c|}{ Attitude Toward Using the Web Site } & 5.15 & & 0.847 & 0.867 \\
\hline & A1 & $\begin{array}{l}\text { Using "the virtual store" was } \\
\text { convenient. }\end{array}$ & 5.14 & 1.73 & & \\
\hline & A2 & $\begin{array}{l}\text { Using "the virtual store" would } \\
\text { save me time. }\end{array}$ & 5.15 & 1.87 & & \\
\hline
\end{tabular}




\begin{tabular}{|l|l|l|l|l|l|l|}
\hline Construct & $\begin{array}{l}\text { Item } \\
\text { Code }\end{array}$ & Items & Mean & $\begin{array}{l}\text { Standard } \\
\text { Deviation }\end{array}$ & $\begin{array}{l}\text { Cronbach's } \\
\text { Alpha }\end{array}$ & $\begin{array}{l}\text { Average } \\
\text { Variance } \\
\text { Extracted }\end{array}$ \\
\hline & A3* & $\begin{array}{l}\text { The fact that I cannot see the } \\
\text { actual products makes me think } \\
\text { twice about using "the virtual } \\
\text { store". }\end{array}$ & 3.63 & 2.02 & & \\
\hline Web Site Usability & US1 & $\begin{array}{l}\text { It is easy to find specific infor- } \\
\text { mation from "the virtual store" }\end{array}$ & 4.94 & 1.74 & & $\mathbf{0 . 9 2 3}$ \\
\hline & US2** & $\begin{array}{l}\text { I feel frustrated when I am using } \\
\text { "the virtual store". }\end{array}$ & 4.90 & 1.96 & & \\
\hline & US3** & $\begin{array}{l}\text { I feel confused when I am using } \\
\text { "the virtual store". }\end{array}$ & 4.97 & 1.93 & & \\
\hline & US4** & $\begin{array}{l}\text { It is hard to search for informa- } \\
\text { tion at "the virtual store". }\end{array}$ & 5.26 & 1.85 & & \\
\hline & $\begin{array}{l}\text { I feel confident that I have found } \\
\text { all the relevant information that I } \\
\text { am looking for at "the virtual } \\
\text { store". }\end{array}$ & 4.93 & 1.56 & & \\
\hline & $\begin{array}{l}\text { Overall, I think "the virtual } \\
\text { store" is usable. }\end{array}$ & 5.47 & 1.73 & & \\
\hline
\end{tabular}

Note. * Item A3 was dropped due to a low Cronbach's alpha.

** Items US2, US3, and US4 were negatively worded items; the participants' responses that were reversed.

Two measures, Cronbach's alpha and the AVE, were used to assess internal consistency reliability for the items. Cronbach's alpha was calculated by XLSTAT, a Microsoft Excel add-in, and all of the final coefficients are significantly greater than 0.70 , the threshold for this study. The values range from 0.828 for the construct Internet Usability to 0.986 for the construct Perceived Ease of Use. The AVE was calculated by PLS-Graph for the post-task questionnaire items. The AVE measures the amount of variance that a construct captures from the measurement items and should be greater than 0.50 which indicates that $50 \%$ of the variance has been accounted for (Chin, 1998). All of the AVE values of all of the constructs exceed the minimum, ranging from 0.564 to 1.000 .

The final coefficient for the construct Attitude toward Using was computed using the answers to only two of its three items from the post-task questionnaire. Item A3 (The fact that I cannot see the actual products makes me think twice about using the "virtual store"), with the lowest mean among all of the items, was removed from the final data analysis. Initially, when the responses to item A3 were included with the responses to items A1 (Using the "virtual store" was convenient) and A2 (Using the "virtual store" would save me time), the result was a Cronbach's alpha coefficient of exactly 0.700 . Removal of item A3's responses improved the coefficient to 0.847 , a more acceptable value.

The means, standard deviations, factor loadings, Cronbach's alpha, and the AVE for the items associated with the construct Actual Usage are shown in Table 3. The range of the scale to capture information about purchases the participants made using e-commerce Web sites is on the "Demographic and Computer Usage" questionnaire and is also from 1 to 7, from having made "0" purchases to having made purchases "More than 10 times" respectively. The Cronbach alpha 
coefficient of 0.923 is significantly greater than 0.70 and the AVE of 0.790 is greater than 0.50 , the thresholds for this study.

Table 3. Summary of Measurement Scales:

Demographic and Computer Usage Questionnaire

\begin{tabular}{|l|l|l|l|c|c|c|}
\hline Construct & $\begin{array}{l}\text { Item } \\
\text { Code }\end{array}$ & Items & Mean & $\begin{array}{c}\text { Standard } \\
\text { Deviation }\end{array}$ & $\begin{array}{c}\text { Cronbach's } \\
\text { Alpha }\end{array}$ & $\begin{array}{c}\text { Average } \\
\text { Variance } \\
\text { Extracted }\end{array}$ \\
\hline \multicolumn{2}{|l|}{ Actual System Usage of the Web Site } & $\mathbf{2 . 2 1}$ & & $\mathbf{0 . 8 9 3}$ & $\mathbf{0 . 7 9 0}$ \\
\hline & AU1 & $\begin{array}{l}\text { How many times during } \\
\text { the past year have you } \\
\text { purchased products or } \\
\text { services from an Internet } \\
\text { Web site? }\end{array}$ & 2.74 & 1.91 & & \\
\hline & AU2 & $\begin{array}{l}\text { How many times during } \\
\text { the past year have you } \\
\text { purchased a book from an } \\
\text { Internet bookstore? }\end{array}$ & 1.89 & 1.50 & & \\
\hline & $\begin{array}{l}\text { How many times during } \\
\text { the past year have you } \\
\text { made an airline reserva- } \\
\text { tion on an Internet Web } \\
\text { site? }\end{array}$ & 2.01 & 1.38 & & \\
\hline
\end{tabular}

The items and constructs were tested for convergent and discriminant validity using confirmatory factor analysis. Convergent validity verifies that the questionnaire items measuring their corresponding construct are theoretically related, highly correlated to each other, and highly correlated to the construct they are intended to measure (Chin, 1998; Sekaran, 2003). Factor loadings measure the strength of the correlation between each item and each construct and are standard outputs of the partial least squares analysis performed by PLS-Graph. As shown in Table 4, the factor loading values (in bold) exceed 0.500, an acceptable minimum value (Chin, 1998), showing that there is a strong correlation between each of the items on their corresponding construct. Each construct, as measured by its assigned items on the questionnaires, demonstrates convergent validity.

Discriminant validity, on the other hand, verifies that the items that demonstrate convergent validity are not highly correlated to any other constructs in the model (Gefen \& Straub, 2005;

Sekaran, 2003). As shown in Table 4, the items that demonstrated convergent validity (values in bold) do not correlate highly with any other constructs. Each construct, as measured by its assigned items on the questionnaires, demonstrates discriminant validity.

Based on the Cronbach'a alpha and the AVE calculations, all of the items used in the analysis of the proposed research model can be accepted as internally reliable and consistent in defining the constructs. Through the use of confirmatory factor analysis, all of the constructs demonstrate acceptable convergent validity and discriminant validity. 
Table 4. Discriminant Validity Correlation Matrix:

Loadings and Cross-Loadings for the Measurement Model

\begin{tabular}{|c|c|c|c|c|c|c|c|c|}
\hline ITEMS & IU & $\mathrm{A}$ & BI & PEOU & PU & $\mathrm{PO}$ & US & $\mathrm{AU}$ \\
\hline IU1 & 0.726 & 0.291 & 0.164 & 0.394 & 0.225 & 0.344 & 0.230 & 0.269 \\
\hline IU2 & 0.855 & 0.600 & 0.286 & 0.641 & 0.436 & 0.459 & 0.467 & 0.091 \\
\hline IU3 & 0.600 & 0.087 & 0.166 & 0.187 & 0.134 & 0.181 & 0.166 & 0.393 \\
\hline IU4 & 0.714 & 0.204 & 0.184 & 0.331 & 0.213 & 0.290 & 0.248 & 0.391 \\
\hline IU5 & 0.834 & 0.536 & 0.326 & 0.591 & 0.517 & 0.449 & 0.473 & 0.288 \\
\hline A1 & 0.605 & 0.937 & 0.551 & 0.863 & 0.593 & 0.691 & 0.767 & 0.050 \\
\hline$\overline{\mathrm{A} 2}$ & 0.388 & 0.926 & 0.613 & 0.649 & 0.685 & 0.677 & 0.654 & 0.041 \\
\hline BI1 & 0.318 & 0.624 & 1.000 & 0.556 & 0.769 & 0.687 & 0.623 & 0.063 \\
\hline PEOU1 & 0.582 & 0.830 & 0.587 & 0.973 & 0.657 & 0.738 & 0.848 & 0.050 \\
\hline PEOU2 & 0.607 & 0.791 & 0.579 & 0.972 & 0.666 & 0.747 & 0.841 & 0.098 \\
\hline PEOU3 & 0.605 & 0.804 & 0.529 & 0.968 & 0.635 & 0.720 & 0.814 & 0.006 \\
\hline PEOU4 & 0.663 & 0.768 & 0.485 & 0.975 & 0.633 & 0.706 & 0.804 & 0.114 \\
\hline PEOU5 & 0.625 & 0.779 & 0.524 & 0.982 & 0.648 & 0.731 & 0.839 & 0.080 \\
\hline PU1 & 0.387 & 0.623 & 0.746 & 0.664 & 0.907 & 0.717 & 0.659 & 0.015 \\
\hline PU2 & 0.384 & 0.532 & 0.647 & 0.509 & 0.933 & 0.711 & 0.608 & 0.095 \\
\hline PU3 & 0.295 & 0.532 & 0.655 & 0.445 & 0.922 & 0.694 & 0.581 & 0.026 \\
\hline PU4 & 0.568 & 0.761 & 0.724 & 0.752 & 0.867 & 0.769 & 0.748 & 0.135 \\
\hline PO1 & 0.395 & 0.595 & 0.493 & 0.640 & 0.601 & 0.878 & 0.695 & 0.213 \\
\hline $\mathrm{PO} 2$ & 0.372 & 0.546 & 0.512 & 0.545 & 0.636 & 0.872 & 0.544 & 0.025 \\
\hline PO3 & 0.517 & 0.773 & 0.766 & 0.772 & 0.846 & 0.908 & 0.798 & 0.126 \\
\hline US1 & 0.651 & 0.789 & 0.617 & 0.867 & 0.769 & 0.838 & 0.886 & 0.155 \\
\hline US2 & 0.316 & 0.678 & 0.528 & 0.753 & 0.591 & 0.647 & 0.906 & 0.100 \\
\hline US3 & 0.304 & 0.622 & 0.484 & 0.756 & 0.537 & 0.585 & 0.889 & 0.098 \\
\hline US4 & 0.267 & 0.646 & 0.588 & 0.678 & 0.598 & 0.643 & 0.878 & 0.010 \\
\hline US5 & 0.442 & 0.513 & 0.446 & 0.554 & 0.597 & 0.600 & 0.686 & 0.330 \\
\hline US6 & 0.418 & 0.704 & 0.639 & 0.697 & 0.716 & 0.802 & 0.853 & 0.069 \\
\hline AU1 & 0.327 & -0.007 & 0.055 & 0.038 & 0.073 & 0.095 & 0.125 & 0.959 \\
\hline AU2 & 0.332 & -0.006 & 0.010 & 0.034 & 0.039 & -0.006 & 0.126 & 0.741 \\
\hline AU3 & 0.277 & 0.018 & 0.070 & 0.095 & 0.077 & 0.140 & 0.158 & 0.950 \\
\hline
\end{tabular}

Note. Construct abbreviations are: IU=Internet Usability; A=Attitude Toward Using; $\mathrm{BI}=$ Behavioral Intention to Use; $\mathrm{PEOU}=$ Perceived Ease of Use; $\mathrm{PU}=$ Perceived Usefulness; $\mathrm{PO}=$ Products and Services; US=Web Site Usability; AU=Actual System Usage. 


\section{Structural Equation Modeling: Partial Least Squares}

PLS-Graph estimated path coefficients between the constructs and the variances between the dependent and independent constructs. The result of that analysis using the proposed research model is shown in Figure 3. The figure presents the constructs and the related measurement items with factor loadings, the amount of variance $\left(R^{2}\right)$ explained in the dependent constructs (Perceived Usefulness of the Web Site, Perceived Ease of Use of the Web Site, Attitude Toward Using the Web Site, Behavioral Intention to Use the Web Site, and Actual System Usage of the Web Site) and the path coefficients for the dependent and independent relationships.

The statistical significance of the causal path between the constructs was determined using $t$ statistics generated by PLS-Graph and was used to either "reject" or "fail to reject" the null hypotheses. The $t$ distribution table, using a one-tailed test and a degrees of freedom of $71(n-1)$, was used to determine the critical value. If the $t$ statistic was greater than the critical value, the null hypothesis was not rejected. If the $t$ statistic was less than or equal to the critical value, the hypothesis was rejected. Of the nine hypotheses, six were rejected and three were not rejected.

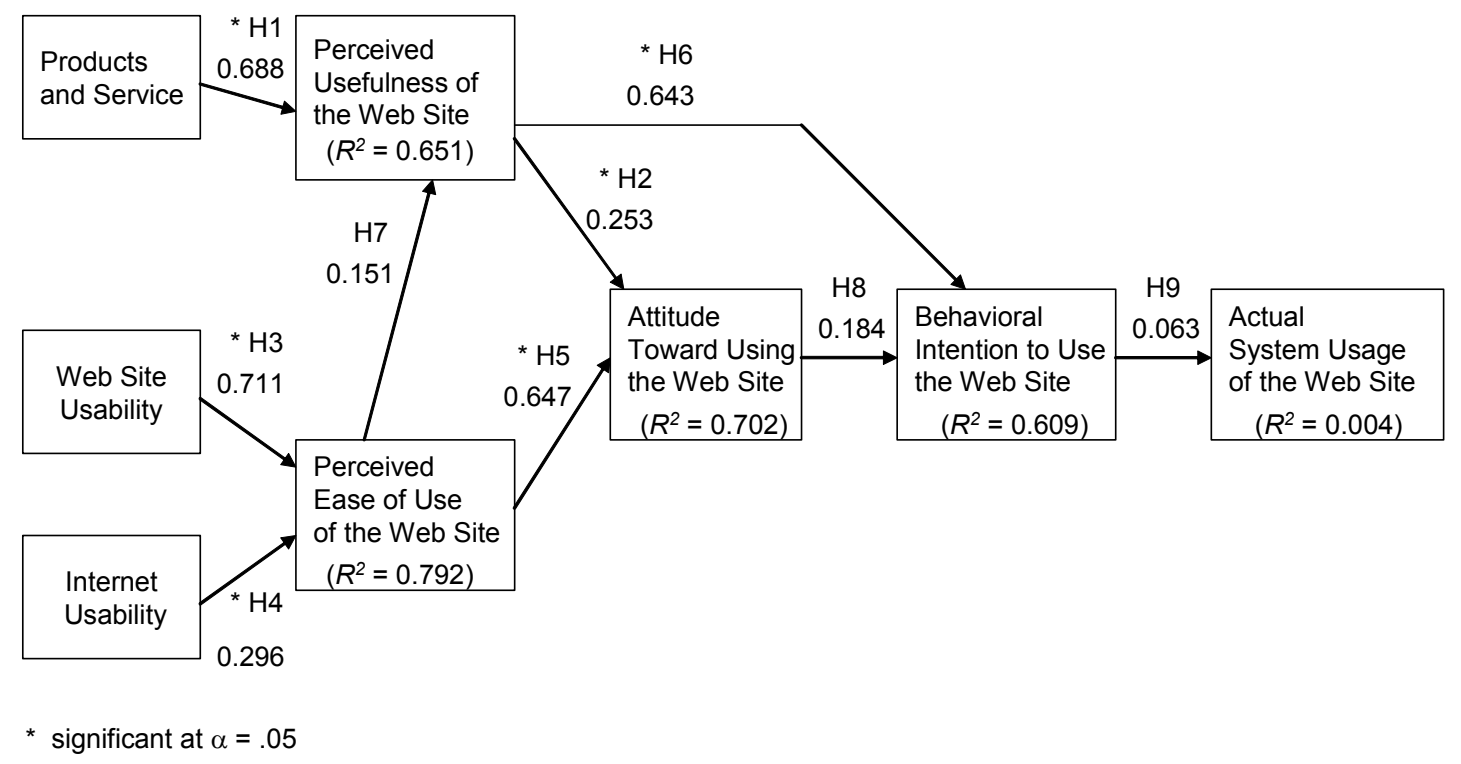

Figure 3. Hypotheses and Model Parameters for the Research Model

The nine null hypotheses and the results of the findings are as follows:

- H1: The senior's perception of the products and services offered by an e-commerce Web site will not have a significant effect on the senior's perceived usefulness of an ecommerce Web site.

The path coefficient between the construct Products and Services and the construct Perceived Usefulness of the Web Site is significant at 0.688 ( $t$ statistic $=9.78$, critical value $=$ $1.67, \alpha=.05)$. H1 should be rejected.

- H2: The senior's perception of the perceived usefulness of an e-commerce Web site will not have a significant effect on the senior's attitude toward using an e-commerce Web site.

The path coefficient between the construct Perceived Usefulness of the Web Site and the construct Attitude Toward Using the Web Site is significant at 0.253 ( $t$ statistic $=2.79$, critical value $=1.67, \alpha=.05$ ). $\mathrm{H} 2$ should be rejected. 
- H3: The senior's perception of the usability of an e-commerce Web site will not have a significant effect on the senior's perceived ease of use of an e-commerce Web site.

The path coefficient between the construct Web Site Usability and the construct Perceived Ease of Use of the Web Site is significant at 0.711 ( $t$ statistic $=10.68$, critical value $=1.67, \alpha=.05)$. $\mathrm{H} 3$ should be rejected.

- H4: The senior's perception of the usability of the Internet will not have a significant effect on the senior's perceived ease of use of an e-commerce Web site.

The path coefficient between the construct Internet Usability and the construct Perceived Ease of Use of the Web Site is significant at 0.296 ( $t$ statistic $=3.87$, critical value $=1.67$, $\alpha=.05)$. H4 should be rejected.

- H5: The senior's perceived ease of use of an e-commerce Web site will not have a significant effect on the senior's attitude toward using an e-commerce Web site.

The path coefficient between the construct Perceived Ease of Use of the Web Site and the construct Attitude toward Using the Web Site is significant at 0.647 ( $t$ statistic $=7.99$, critical value $=1.67, \alpha=.05)$. H5 should be rejected.

- H6: The senior's perceived usefulness of an e-commerce Web site will not have a significant effect on the senior's behavioral intention to use an e-commerce Web site.

The path coefficient between the construct Perceived Usefulness of the Web Site and the construct Behavioral Intention to Use the Web Site is significant at 0.643 ( $t$ statistic $=$ 5.57 , critical value $=1.67, \alpha=.05)$. H6 should be rejected.

- H7: The senior's perceived ease of use of an e-commerce Web site will not have a significant effect on the senior's perceived usefulness of an e-commerce Web site.

The path coefficient between the construct Perceived Ease of Use of the Web Site and the construct Perceived Usefulness of the Web Site is not significant at 0.151 ( $t$ statistic $=$ 1.63 , critical value $=1.67, \alpha=.05)$. H7 should not be rejected.

- H8: The senior's attitude toward using an e-commerce Web site will not have a significant effect on the senior's behavioral intention to use an e-commerce Web site.

The path coefficient between the construct Attitude Toward Using the Web Site and the construct Behavioral Intention to Use the Web Site is not significant at $0.184(t$ statistic $=$ 1.31 , critical value $=1.67, \alpha=.05)$. H8 should not be rejected.

- H9: The senior's behavioral intention to use an e-commerce Web site will not have a significant effect on predicting the senior's actual use of an e-commerce Web site.

The path coefficient between the construct Behavioral Intention to Use the Web Site and the construct Actual System Usage of the Web Site is not significant at 0.063 ( $t$ statistic $=$ 0.39 , critical value $=1.67, \alpha=.05$ ). H9 should not be rejected.

Given that statistically significant results were not found for null hypotheses $\mathrm{H} 7, \mathrm{H} 8$, and H9, it was important to estimate the probability that a Type II error occurred. The power of a statistical test is the probability of making a decision to reject a null hypothesis when it is false and the probability that a Type II error occurred is the complement of the statistical power (Cohen, 1998; Kline, 2004). In a post hoc power analysis, three parameters are used to compute the power of the test and the probability that a Type II error occurred. The parameters are: 1) the sample size; 2) the alpha level; and 3) the effect size. The effect size is the strength of the relationship among the independent and dependent constructs being tested in each of the null hypotheses (Kline, 
2004) and is provided in the output of PLS-Graph as Pearson correlation coefficients. To determine the power of the test and the probability of a Type II error, Cohen's Pearson productmoment correlation power table can be used when all three of the parameters are known.

Pertaining to H7, the Pearson correlation between the senior's perceived ease of use of an ecommerce Web site and the senior's perceived usefulness of an e-commerce Web site was 0.666. In this study, the sample size was 72 data cases and the alpha level was set at .05. Using Cohen's (1988) power table and a one-tailed test, the power of this test was $>.995$ and the probability of a Type II error was $<.005$.

Pertaining to H8, the Pearson correlation between the senior's attitude toward using an ecommerce Web site and the senior's behavioral intention to use an e-commerce Web site was 0.624. Using Cohen's (1988) power table, the power of this test was $>.995$ and the probability of a Type II error was $<.005$.

Pertaining to H9, the Pearson correlation between the senior's behavioral intention to use an ecommerce Web site and the senior's actual use of an e-commerce Web site was 0.063 . Using Cohen's (1988) power table, the power of this test was $<=.21$ and the probability of a Type II error was $>=.79$.

The research model contains many dependent-independent construct relationships that were also analyzed using PLS-Graph. The relationships and the findings are as follows:

- Sixty-five percent of variance in the dependent construct Perceived Usefulness of the Web Site is explained by two independent constructs, Perceived Ease of Use of the Web Site and Products and Services. The path coefficients indicate that between the two independent constructs, Products and Services exerts a much greater influence (0.688) than does Perceived Ease of Use of the Web Site (0.151).

- Seventy-nine percent of variance in the dependent construct Perceived Ease of Use of the Web Site is explained by two independent constructs, Web Site Usability and Internet $U_{S}$ ability. The path coefficients indicate that between the two independent constructs, $\mathrm{Web}$ Site Usability exerts a greater influence (0.711) than does Internet Usability (0.296).

- Seventy percent of variance in the dependent construct Attitude toward Using the Web Site is explained by two independent constructs, Perceived Ease of Use of the Web Site and Perceived Usefulness of the Web Site. The path coefficients indicate that between the two independent constructs, Perceived Ease of Use of the Web Site exerts a greater influence (0.647) than does Perceived Usefulness of the Web Site (0.253).

- Sixty-one percent of variance in the dependent construct Behavioral Intention to Use the Web Site is explained by two independent constructs, Perceived Usefulness of the Web Site and Attitude toward Using the Web Site. The path coefficients indicate that between the two independent constructs, Perceived Usefulness of the Web Site exerts a greater influence (0.643) than does Attitude toward Using the Web Site (0.184).

- Less than one percent of the variance in the primary dependent construct Actual System Usage of the Web Site is explained by the independent construct, Behavioral Intention to Use the Web Site

\section{Participant and Web Site Usability Observations}

All of the computer monitors were set with a screen resolution of 1280 by 1024 pixels except one that was set at 800 by 600 pixels. Since many of the participants wore eyeglasses and some of them had either bifocals with a lens for computer use or a separate pair of eyeglasses, the 1280 by 
1024 resolution was acceptable. One monitor was set at 800 to 600 pixels and that increased the problems with navigation, especially on the travel sites when a long list of available flights, hotels, and other attractions and services was displayed. The amount of horizontal and vertical scrolling caused by this resolution resulted in increased amount of confusion and frustration by the participant that used this computer.

The quantitative data collected on the usability test log from the 72 Web site tests is summarized, by Web site, in Table 5 . The average times spent testing the online bookstores were much less than the times taken on the travel sites. This was caused by two factors. First, the test script to make an airline reservation included many more steps to complete when compared to the test script to find two books and add them to the shopping cart. The second factor was the complexity of the shopping experience. The travel sites required the user to enter passenger data, select seats for the flights, and, in the case of Travelocity.com, required the user to become a member of Travelocity by entering the participant's name, address and other demographic information.

Table 5. Descriptive Statistics - Participant Test Statistics

\begin{tabular}{|l|c|c|c|c|}
\hline & Barnes and Noble & Booksamillion & Orbitz & Travelocity \\
\hline Tests per Site & 19 & 19 & 17 & 17 \\
\hline $\begin{array}{l}\text { Average Com- } \\
\text { pletion Time }\end{array}$ & 9 minutes & 12 minutes & 18 minutes & 19 minutes \\
\hline Successful Tests & $100 \%$ & $100 \%$ & $82 \%$ & $65 \%$ \\
\hline Errors Made & 5 & 4 & 6 & 9 \\
\hline Requests for Help & 5 & 4 & 7 & 11 \\
\hline
\end{tabular}

All of the tests on the online bookstores were successfully completed but not all of the tests were successfully completed on the travel sites. Eighty-two percent of the participants successfully completed the tasks on Orbitz.com and 65\% were successful on Travelocity.com. Two common mistakes were responsible for the unsuccessful tests. First, the task instructions required the participant to request flight reservations for two passengers. Some of the participants entered a "2" in the "Adults" field and also entered " 2 " in the "Seniors" field, resulting in reservations for four passengers. Even though they realized that this occurred, they continued on with the test. The second most common mistake that occurred was that the participants did not select the seats for the second or return flight.

Errors were made during every test on every site. The most common one on the online bookstore Web sites occurred when the participants were changing the quantity of each book in the shopping cart. Both Barnesandnoble.com and Booksamillion.com required the customer to click on an "Update Quantity" link if changes were made to the shopping cart. If the participant did not update, the quantities did not change in the shopping cart. Most of the participants realized the mistake and recovered from it.

There were two very common errors made on the travel sites. First, both sites required e-mail addresses for contact information. For verification, the e-mail address was entered two times. In error, either the participant mistyped the e-mail address or missed entering it the second time. The second most common error occurred during the seat selection process. Seats were selected on Orbitz.com by clicking on an icon representing an available seat. Travelocity.com, on the other hand, showed the seat map and available seats, but did not offer the same functionality. On Travelocity.com the user had to type the row and seat number into fields that are part of the pas- 
senger information. Because of this difference, some participants did not correctly select seats for all of their flights.

As the participants completed the task instructions for each Web site, they were encouraged to "Think Aloud" which allowed the researcher to log positive and negative comments made about the site. These comments often addressed navigation throughout the Web site, the use of background colors and fonts, and the overall layout of the Web site.

The page used to search for books on Barnesandnoble.com received favorable comments from many of the participants because they were able to easily find the search fields and they understood the layout of the page and the need to enter information into the search fields. It was clear to the researcher that the participants understood how to navigate the page and to use the search fields.

The home page of Booksamillion.com also received favorable comments from many of the participants, especially about the amount of open or white space on the page. They found it easy to understand and liked the fact that it was not cluttered with a lot of advertisements. The site had consistent navigation links, the searches for both the author and the title returned the correct books, and the pages were easy to see and read. The only negative comments made were about the instructions on how to change quantities or remove books from the shopping cart.

The home page of Orbitz.com received many unfavorable comments, especially about the light blue color that was used in the background of the Web pages. Even more troubling for some participants was the use of blue text against this same background which caused many of the participants to lean forward, closer to the computer monitor. In one participant's words, this Web page was not "senior friendly". After selecting the departure and return flights, a Web page was displayed that confirmed the flight number, the times, and the dates for each flight. On the same page a long list of hotel options was displayed immediately following the flight details. The participant then had to do extensive vertical scrolling to bypass the hotel offers and continue with the testing. Not only was this distracting to some participants, many of them saw this as unnecessary because they only requested flight information and did not want to be bothered with hotel, car rental, and other miscellaneous information.

The home page of Travelocity.com used bold colors with dark type, a combination well received by many of the participants. A primary frustration with Travelocity.com was its requirement that the person making the airline reservation become a member of Travelocity and provide his/her name, address, phone numbers, and other personal information early in the reservation process. Becoming a member was required immediately after the departure and return flights were selected and just prior to selecting the seats for each flight. The entry of the demographic information was tedious and time consuming, causing some of the difference in the average test times.

As noted earlier, the seat selection process on Travelocity.com also caused some frustration and confusion. During seat selection the participants expected to be able to place the cursor on any available seat in the map, mouse click on the seat, and have the seat information automatically be entered in each flight reservation. This was not, however, the functionality provided on this Web page and it took some participants a few moments to realize that selecting the seat did nothing at all. To select a seat on this travel site, each participant had to manually enter the row and seat number in the appropriate box next to the passenger's name. Seat selection was not, according to some participants, intuitive or easy to use. 


\section{Conclusions}

The results of this research show that six of the nine null hypotheses of the research model could be rejected and that the research model is generally plausible. The model clearly shows that seniors have a behavioral intention to use e-commerce Web sites if the Web site is perceived as useful.

The perceived ease of use of an e-commerce Web site had a positive but not a significant effect on a senior's perception of the usefulness of the Web site. The relationship between these two constructs has been tested in previous studies and the findings suggest that the significance of this relationship often changes from one study to another. In this study, the ease of use items in this study only measured the ease with which products could be found on the Web sites and did not measure the ease with which products could be purchased on the Web sites. It may be that the decision to only search for products on the Web sites but not purchase any of them may have reduced the influence that the construct Perceived Ease of Use of the Web Site has on the construct Perceived Usefulness of the Web Site.

A senior's attitude toward using an e-commerce Web site had a positive but not significant effect on a senior's behavioral intention to use an e-commerce Web site. Consistent with prior findings, the path coefficients indicate that the independent construct, Perceived Usefulness of the Web Site, has a significantly greater effect on a senior's intention to use a Web site when compared to the Attitude toward Using the Web Site. The insignificance of the relationship between the attitude toward using and the behavioral intention to use an e-commerce Web site suggests that seniors will first determine if Web site will satisfy their wants or needs, thus considering it useful, before they ever visit the site. Only if a senior intends to visit a site will the ultimate attitude toward the site, a variable that mediates the influence of the perceived ease of use and the usefulness of the site, exert any influence.

A senior's behavioral intention to use an e-commerce Web site had a positive but not significant effect on a senior's decision to actually use and purchase from the Web site. Although this was a surprise to the researcher, it may be explainable. The significance of the intention to use the Web site, which was posited to translate into actual use, appears to be tempered by the statistical influence of the items used to measure actual system use. Previous online experience, captured by responses to the three items that were used to measure a senior's prior purchasing experience, resulted in participants with both high and low usage, representing some long time users and novices respectively. Thirty-eight percent of the sample had not made any purchases using the Internet and perhaps their responses subdued any influence the construct Behavioral Intention to Use the Web Site exerted on the construct Actual System Use of the Web Site, reducing the effect size in this test. It could be that although seniors may indicate an intention to use a Web site, primarily influenced by the perceived usefulness of the Web site, if it is unusable, actual use may never occur.

Two factors were posited to influence a senior's perception of the ease of use of the Web site, the constructs Web Site Usability and Internet Usability. The path coefficients indicate that between the two independent constructs, Web Site Usability exerts a greater influence than does Internet Usability. Once a senior is confident he/she can use the Internet, it then becomes the usability of the Web site that exerts the most influence.

Of significant worth is the test of the robustness of the Technology Acceptance Model (TAM) when applied to e-commerce adoption by seniors. With the exception of the very weak relationship between the behavioral intention to use an e-commerce Web site and the actual use of a Web site, the model's predictive and explanatory capabilities still hold true. Useful Web sites have products or services that consumers need or want. The relationship between a Web sites' per- 
ceived usefulness and the behavioral intention to use the Web site is still strong. The long established causal relationship between perceived ease of use and attitude toward using the Web site was also strong. The highlight finding of this study, however, is the influence of Web site usability and, to a lesser but still important extent, the influence of Internet usability on the perceived ease of use of e-commerce Web sites.

The researcher observed that seniors found usability issues with all four of the test Web sites and it was obvious that both of the travel sites were more difficult to use when compared to the online bookstores. However, it appears that if a Web site and the products and services it offers is perceived as useful, seniors will attempt to try to overcome any usability issues. It is clear to the researcher that if seniors can overcome computer and Internet usability barriers, they could become eager and willing adopters of these technologies.

Web designers should understand that Web sites must be both useful and easy to use and that the aging process can directly influence how easy a Web site will be to use. The deterioration of vision, hearing, short-term memory, and motor skills can make it difficult for seniors to understand and navigate Web sites. Based on many of the observations made during this study, designers should focus on removing obvious obstacles to Web site usability, obstacles such as the poor use of background colors, font sizes, inconsistent page layouts, and the presentation of pages cluttered with ads and miscellaneous information. The ease of navigation, the ease of learning, and the ease of understanding the Web site are necessary if seniors are to become visitors and purchasers on online e-commerce Web sites.

Finally, the researcher was concerned about the testing process and, specifically, participant fatigue. Although some of the participants took longer than others, not one of them expressed concern about the length or the complexity of the tasks. All of the participants were enthusiastic supporters of the research and were excited to be participating is such a study. Some of the participants stated that the opportunity to learn about e-commerce Web sites and the purchasing process was both exciting and enjoyable. Many of them planned to return to some of the Web sites and purchase books or make travel reservations.

\section{Limitations}

Although a number of conclusions have been drawn as a result of this study, it is important to review some of the limitations against which these conclusions should be judged. First, this was a purposeful sample and limits generalizability. Second, although the sample size of 72 data cases resulted in acceptable statistical power for testing eight of the nine null hypotheses, a larger sample size may produce different and statistically better results. Increasing the sample size will increase the statistical power analysis and reduce the probability of Type II error. Third, the participants may not adequately represent the larger senior population both in computer literacy, Internet usage, and Web expertise. Finally, the four Web sites used in the testing came from two industries, travel and books, and may not fully represent the design, functionality, and usability of all of the types of e-commerce Web sites. Some companies may spend more time and money and allocate more resources to designing and developing usable Web interfaces, while others may not.

\section{Directions for Future Research}

Regarding future research, researchers should conduct studies that address the following:

1. Additional research is necessary to examine the generalizability of the findings by testing the research model with senior participants from other senior-based organizations. Collecting data across multiple organizations would improve the generalizability. 
2. Conduct the same study with a larger sample as a means of increasing the statistical power and reducing the potential for Type II error.

3. Conduct the same study with participants from the baby boomer generation, the generation that will be primarily responsible for the rapid growth in the senior population over the next two decades. It would be most interesting to see if Internet usability and/or Web site usability had the same or less of an influence on perceived ease of use of e-commerce Web sites when compared to the findings in this paper.

4. Conduct the same study with participants from today's student population, the generation that is increasingly using e-commerce and social Web sites through the Internet and the World Wide Web.

5. Test using seniors with varying degrees of sensory, cognitive, and mobility impairments and with and without the use of assistive devices.

6. Test only with seniors that have already used the Internet to purchase products or services. This change in the sample requirements, from just testing with Internet users, may improve the effect size and the causal relationship between the behavioral intention to use e-commerce Web sites and actual usage.

7. Alter the research model to remove the insignificant causal relationships identified in this study. First, remove the construct Actual System Usage of the Web Site and terminate the model with Behavioral Intention to Use the Web Site. Secondly, remove the construct Attitude Toward Using the Web Site and instead posit that both the Perceived Ease of Use of the Web Site and the Perceived Usefulness of the Web Site directly effect a senior's Behavioral Intention to Use the Web Site.

\section{References}

Agarwal, R., \& Venkatesh, V. (2002). Assessing a firm's Web presence: A heuristic evaluation procedure for the measurement of usability. Information Systems Research, 13(2), 168-186.

Becker, S. A. (2004). A study of Web usability for older adults seeking online health resources. $A C M$ Transactions on Computer-Human Interaction, 11(4), 387-406.

Burton-Jones, A., \& Hubona, G. S. (2005). Individual differences and usage behavior: Revisiting a technology acceptance model assumption. Database for Advances in Information Systems, 36(2), 58-77.

Chen, C. (2003). An investigation of significant factors affecting consumer trust in e-commerce. Dissertation Abstracts International, 64(9), 3376. (UMI No. 3106539).

Chen, L., Gillenson, M. L., \& Sherrell, D. L. (2004). Consumer acceptance of virtual stores: A theoretical model and critical success factors for virtual stores. ACM SIGMIS Database, 35(2), 8-31.

Chin, W. H. (1998). Partial least squares approach to structural equation modeling. In G. A. Marcoulides (Ed.), Modern methods for business research (pp. 295-336). Mahwah, NJ: Lawrence Erlbaum Associates.

Cohen, J. (1988). Statistical power analysis for the behavioral sciences. Hillsdale, NJ: Lawrence Erlbaum Associates Publishing.

Coyne, K. P., \& Nielsen, J. (n.d.). Web usability for senior citizens. Retrieved April 14, 2007, from http://www.nngroup.com/reports/seniors/

Cutler, S. J. (2005). Ageism and technology. Generations, 29(3), 67-72.

Davis, F. D. (1989). Perceived usefulness, perceived ease of use, and user acceptance of information technology. MIS Quarterly, 13(3), 319-340. 
Devaraj, S., Fan, M., \& Kohli, R. (2002). Antecedents of B2C channel satisfaction and preference: Validating e-commerce metrics. Information Systems Research, 13(3), 316-333.

Fox, S. (2004). Older Americans and the Internet. Retrieved April 14, 2007, from http://www.pewinternet.org/pdfs/PIP Seniors Online 2004.pdf

Gefen, D., Karahanna, E., \& Straub, D. W. (2003). Trust and TAM online shopping: An integrated model. MIS Quarterly, 27(1), 51-90.

Gefen, D., \& Straub, D. W. (2005). A practical guide to factorial validity using PLS-Graph: Tutorial and annotated example. Communications of the Association for Information Systems, 16, 91-109.

Gefen, D., Straub, D. W., \& Boudreau, M. (2000). Structural equation modeling and regression: Guidelines for research practice. Communication of AIS, 4(7), 2-77.

Gregor, P., \& Newell, A. F. (2001). Designing for dynamic diversity - Making accessible interfaces for older people. Proceedings of the 2001 EC/NSF Workshop on Universal Accessibility of Ubiquitous Computing: Providing for the Elderly, Alcacer do Sal:Portugal, 90-92.

Hanson, V. (2001). Web access for elderly citizens. Proceedings of the 2001 EC/NSF Workshop on Universal Accessibility of Ubiquitous Computing: Providing for the Elderly, Alcacer do Sal:Portugal, 14-18.

Hawthorn, D. (2000). Possible implications of aging for interface designers. Interacting with Computers, $12(5), 507-528$.

Jacko, J. A., Scott, I. U., Sainfort, F., Barnard, L., Edwards, P. J., Emery, V. K., et al. (2003). Older adults and visual impairment: What do exposure times and accuracy tell us about performance gains associated with multimodal feedback? Proceedings of the Conference on Human Factors in Computing Systems, USA, 33-40.

Kline, R. B. (2004). Beyond significance testing. Washington, DC: American Psychological Association.

Kline, R. B. (2005). Principles and practice of structural equation modeling (2nd ed.). New York, NY: The Guilford Press.

Klopping, I. M., \& McKinney, E. (2004). Extending the technology acceptance model and the tasktechnology fit model to consumer e-commerce. Information Technology, Learning, and Performance Journal, 22(1), 35-48.

Koufaris, M. (2000). System design and consumer behavior in electronic commerce. Dissertation Abstracts International, 61(9), 3661. (UMI No. 9988944).

Lederer, A. L., Maupin, D. J., Sena, M. P., \& Zhuang, Y. (2000). The technology acceptance model and the World Wide Web. Decision Support Systems, 29(3), 269-282.

Liang, T., \& Lai, H. (2002). Effect of store design on consumer purchases: An empirical study of on-line bookstores. Information \& Management, 39(6), 431-444.

Mayhew, D. J. (1999). The usability engineering lifecycle. San Francisco, CA: Morgan Kaufman Publishers, Inc.

National Eye Institute. (2002, March 20). More Americans facing blindness then ever before. Retrieved April 14, 2007, from http://www.nationaleyeinstitute.org/news/pressreleases/032002.asp

O'Donnell, J. B. (2002). Assessment of the impact of Web site design on consumer trust and the purchase decision. Dissertation Abstracts International, 63(8), 2936. (UMI No. 3063155).

Park, J. J. (2003). Understanding consumer intention to shop online: A model comparison. Dissertation Abstracts International, 64(5), 1448. (UMI No. 3091952).

Rettie, R. (2002). Net generation culture. Journal of Electronic Commerce Research, 3(4), 254-263.

Rogers, W. A., \& Fisk, A. D. (2002). Human factors interventions for the health care of older adults. Mahwah, NJ: Lawrence Erlbaum Associates. 
Savitskie, K., Royne, M. B., Persinger, E. S., Grunhagen, M., \& Witte, C. L. (2007). Norwegian Internet shopping sites: An application \& extension of the technology acceptance model. Journal of Global Information Technology Management, 10(4), 54-73.

Sekaran, U. (2003). Research methods for business: A skill-building approach. (4th ed.). Hoboken, NJ: John Wiley \& Sons.

Singh, N., Fassott, G., Chao, M. C. H., \& Hoffman, J. A. (2006). Understanding international Web site usage: A cross-national study of German, Brazilian, and Taiwanese online consumers. International Marketing Review, 23(1), 83-97.

Suh, B., \& Han, I. (2003). The impact of customer trust and perception of security control on the acceptance of electronic commerce. International Journal of Electronic Commerce, 7(3), 135-161.

U.S. Census Bureau. (2004). Projected population of the United States, by age and sex: 2000 to 2050. Retrieved April 14, 2007, from http://www.census.gov/ipc/www/usinterimproj/natprojtab02a.xls

U.S. Department of Commerce. (2004). United States Department of Commerce News. Retrieved April 14, 2007, from http://www.census.gov/mrts/www/data/html/04Q2.html

U.S. Department of Commerce. (2006a). United States Department of Commerce News. Retrieved April 14, 2007, from http://www.census.gov/mrts/www/data/html/06Q2.html

U.S. Department of Commerce. (2006b). United States Department of Commerce News. Retrieved April 14, 2007, from http://www.census.gov/mrts/www/data/html/06Q4.html

U.S. Department of Commerce. (2007). United States Department of Commerce News. Retrieved April 9 , 2008, from http://www.census.gov/mrts/www/data/html/07Q4.html

Van Gerven, P. W. M., Paas, F., Van Merrienboer, J. G., Hendriks, M., \& Schmidt, H. G. (2003). The efficiency of multimedia learning into old age. British Journal of Educational Psychology, 73(4), 489-505.

Venkatesh, V. (2000). Determinants of perceived ease of use: Integrating control, intrinsic motivation, and emotion into the technology acceptance model. Information Systems Research, 11(4), 342-365.

\section{Biography}

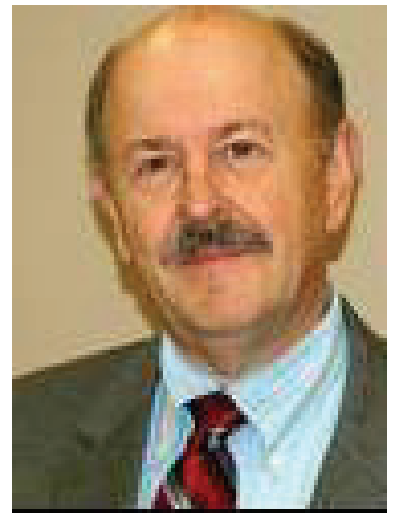

Terry Smith is an assistant professor in the School of Information Technology at Macon State College in Macon, Georgia. He holds a M.B.A. from the University of South Florida in Tampa, Florida, and a $\mathrm{Ph} . \mathrm{D}$. in Information Systems from Nova Southeastern University in Ft. Lauderdale, Florida. His research interests include humancomputer interaction, Web and Internet technologies, E-business, Ecommerce, and E-government. 